\title{
Competition in the Georgian banking sector and its impact on the credit policy of commercial banks
}

\author{
George Abuselidze ${ }^{*}$, and Mariam Sharabidze ${ }^{2}$ \\ ${ }^{1,2}$ Batumi Shota Rustaveli State University, Department of Finance, Banking and Insurance, 35 \\ Ninoshvili Street, Batumi, 6010, Georgia
}

\begin{abstract}
Based on the role of banking sector in the development of the country's economy, we consider it important to study the current situation in this sector. The existence of a competitive environment ensures the efficient functioning of the banking sector. The aim of the study is to estimate the competitive environment in the banking sector, to determine the relationship between competition and interest rates. The research is based on the use of different economic models and indexes. Competition in the banking sector is studied on the example of Georgian banking sector, for that we used HHI Net Loans and H-statistic indicators. The study analyses the impact of competition in the banking sector on the net interest income and interest rate in the same sector.
\end{abstract}

\section{Introduction}

The sustainable banking sector has a great importance for the development of the inclusive economy of the country. The viability of the economy depends on the purposeful functioning of the banking sector. The effective competition environment in banking sector has a positive impact on all participants of financial system. It should also be noted that the banking sector is mainly limited to cash-lending operations inside and outside the country. Accordingly, the banking sector contributes cash flow and unites all economic participants. Therefore, the problems that arise in this sector immediately affect the whole economy. So it is advisable to monitor the risks and crises in banking sector constantly to avoid potential danger that could cause a significant problem to the country's economy. The sustainability and stability of the banking sector has a significant impact on the country's economy. It can be said, that the banking market is accelerating the country's inclusive economic growth. The highly competitive banking sector is a contributing factor to the country's economic growth.

\section{Methodological foundations}

\footnotetext{
* Corresponding author: george.abuselidze@gmail.com
} 


\subsection{Research methods}

The research uses analysis and synthesis, statistical observations, economic-statistical methods of research. By the methods of analysis and synthesis we researched competition in Georgian banking sector based on various financial indicators for to assess the current situation and make conclusions. Statistical observation is used to gather the information needed to calculate all the economic models in the study. Using economic-statistical methods, we used statistical information to identify the relationship between the economical issues.

\subsection{Literature review}

A global Covid-19 Pandemic of the 21st Century changed the structure of the economy, business models, created qualitatively new crises [1-3]. Increase of money in circulation, in parallel of dealing difficulties in the social sphere [4], has faced to countries the difficulties of inflation and deflation. In such situation, the sustainable functioning of the banking sector is especially important to maintenance the money supply balance and prompte inclusive economic growth. There are numerous studies of banking competition [5-11]. According to the modern literature, the competition is a guarantee of the sustainable banking sector [1114]. According to the empirical research of Shaeck et al (2009; 2012; 2014) [15-17] and Boyd et al (2005) [18], the competitive banking sector is less likely to generate banking crises and, moreover, banking competition supports country's economic growth and financial stability [14, 17-21]. In their study, Bukvic (2020) [22], Cuestas et al (2020) [23] and Manju Jayakumar et al (2018; 2019) [24-25], showed relationship between bank competition, stability and economic growth. Beridze (2016) [26] and Dincer (2019) [27] studied banking competition using the H-statistics method. However, the interrelation between the level of competition in the banking sector and the interest rate spread is less studied. And, their impact on the money supply in circulation.

\section{Results and discussion}

Competition is a positive phenomenon for many industries. Its effect can be also positively assessed for the functioning of banking sector. The banking sector plays an important role in flow of money in the economy. Competition is very important for banking sector for many reasons. As in any other businesses, also in the banking sector competition can have a significant impact on the efficiency the provision of banking services, the quality of the banking services, the quality of innovation in banking, the supply of money in economic and etc.

The important role of competition in the banking sector can be defined by the following six reasons: providing the appropriate quality of banking services for customers; promoting the efficient functioning of banking sector; stability of banking system; effective management of banking operations; improving monetary policy and promote inclusive economic growth.

To demonstrate/analysis the interrelation between competition in banking sector and interest rates, also for to assess their role in the money supply, we examined the level of competition in Georgian banking sector by using H-statistic [14, 26-28].

$$
\begin{gathered}
H_{\text {stat }}=\beta_{A F R}+\beta_{\text {PONILE }}+\beta_{P P E}=h 1+h 2+h 3 \\
=\left\{\begin{array}{c}
\leq 0 \text { Monopoly or Monopoly Competition } \\
\in(0,1) \text { Monopoly Competition } \\
=1 \text { Perfect Competition }
\end{array}\right.
\end{gathered}
$$

We have studied the data of commercial banks for 2016-2019 (see Table 1). 
The result of H-statistic shows decreasing trend in 2016-2019, which indicates, that monopoly situation is aggravating in banking sector of Georgia. The result of H-statistic is getting closer to 0 in recent years.

Table 1. H - Statistic 2016-2019.

\begin{tabular}{|c|c|c|c|c|c|c|c|c|}
\hline & \multicolumn{5}{|c|}{ Net interest income } & \multicolumn{3}{|c|}{ Net interest income, \% } \\
\hline $\begin{array}{c}\text { Commercial } \\
\text { Banks }\end{array}$ & 2016 & 2017 & 2018 & 2019 & 2016 & 2017 & 2018 & 2019 \\
\hline $\begin{array}{c}\text { Bank of } \\
\text { Georgia }\end{array}$ & 535182000 & 644547000 & 731544000 & 783573000 & 32,47 & 33,83 & 33,39 & 34,06 \\
\hline Basisbank & 65953000 & 78628000 & 93557000 & 115872000 & 4,00 & 4,13 & 4,27 & 5,04 \\
\hline $\begin{array}{c}\text { Silk Road } \\
\text { Bank }\end{array}$ & 2517000 & 2179000 & 3650000 & 4715000 & 0,15 & 0,11 & 0,17 & 0,20 \\
\hline Credo Bank & 96179000 & 90550000 & 101170000 & 120512000 & 5,84 & 4,75 & 4,62 & 5,24 \\
\hline Cartu Bank & 70592000 & 74513000 & 60995000 & 63619000 & 4,28 & 3,91 & 2,78 & 2,77 \\
\hline $\begin{array}{c}\text { FINCA Bank } \\
\text { Georgia }\end{array}$ & 33958150 & 34849953 & 31722370 & 34792271 & 2,06 & 1,83 & 1,45 & 1,51 \\
\hline $\begin{array}{c}\text { Halyk Bank } \\
\text { Georgia }\end{array}$ & 17276000 & 22583000 & 25029000 & 24249000 & 1,05 & 1,19 & 1,14 & 1,05 \\
\hline $\begin{array}{c}\text { Isbank } \\
\text { Georgia }\end{array}$ & 8481000 & 8255000 & 8388000 & 12461000 & 0,51 & 0,43 & 0,38 & 0,54 \\
\hline TeraBank & 27064000 & 33601000 & 42127000 & 43881000 & 1,64 & 1,76 & 1,92 & 1,91 \\
\hline $\begin{array}{c}\text { Liberty } \\
\text { Bank }\end{array}$ & 150782000 & 181545000 & 182544000 & 165647000 & 9,15 & 9,53 & 8,33 & 7,20 \\
\hline $\begin{array}{c}\text { PASHA } \\
\text { Bank } \\
\text { Georgia }\end{array}$ & 16587000 & 15474000 & 16132000 & 17960000 & 1,01 & 0,81 & 0,74 & 0,78 \\
\hline $\begin{array}{c}\text { ProCredit } \\
\text { Bank }\end{array}$ & 68317000 & 52727000 & 51607000 & 48172000 & 4,14 & 2,77 & 2,36 & 2,09 \\
\hline \begin{tabular}{c} 
TBC Bank \\
\hline $\begin{array}{c}\text { VTB Bank } \\
\text { Georgia }\end{array}$
\end{tabular} & 489288000 & 601567000 & 770558000 & 793240000 & 29,69 & 31,58 & 35,17 & 34,48 \\
\hline $\begin{array}{c}\text { Ziraat Bank } \\
\text { Georgia }\end{array}$ & 2803056 & 3058388 & 4433829 & 6441236 & 0,17 & 0,16 & 0,20 & 0,28 \\
\hline
\end{tabular}

Source: Compiled by the author based on data from the National Bank of Georgia, 2016-2020 [13, 14, 29-32].

In order to evaluate the infallibility of the research, we use another method to measure competition in Georgian banking sector - The Herfindahl-Hirschman Index (HHI). This method is based on net loans portfolios for all commercial banks in banking sector (see Table 2). 
Table 2. HHI Net Loans method 2016-2019.

\begin{tabular}{|c|c|c|c|c|c|c|c|c|}
\hline \multirow{3}{*}{ Commercial Banks } & \multicolumn{2}{|c|}{2016} & \multicolumn{2}{|c|}{2017} & \multicolumn{2}{|c|}{2018} & \multicolumn{2}{|c|}{2019} \\
\hline & \multicolumn{2}{|c|}{ Net loans method } & \multicolumn{2}{|c|}{ Net loans method } & \multicolumn{2}{|c|}{ Net loans method } & \multicolumn{2}{|c|}{ Net loans method } \\
\hline & Dn & $D n^{2}$ & Dn & $D n^{2}$ & Dn & $D n^{2}$ & Dn & $D n^{2}$ \\
\hline Bank of Georgia & $33,52 \%$ & 1123,31 & $34,10 \%$ & 1162,88 & $34,66 \%$ & 1201,11 & $36,35 \%$ & 1321,1 \\
\hline Basisbank & $3,12 \%$ & 9,74668 & $3,47 \%$ & 12,0485 & $3,42 \%$ & 11,7157 & $3,08 \%$ & 9,50933 \\
\hline Silk Road Bank & $0,04 \%$ & 0,00184 & $0,03 \%$ & 0,00086 & $0,06 \%$ & 0,00369 & $0,04 \%$ & 0,00169 \\
\hline Credo Bank & $2,33 \%$ & 5,42637 & $2,36 \%$ & 5,55225 & $2,58 \%$ & 6,67113 & $2,61 \%$ & 6,82551 \\
\hline Cartu Bank & $4,49 \%$ & 20,1428 & $3,64 \%$ & 13,254 & $3,12 \%$ & 9,7531 & $2,75 \%$ & 7,58716 \\
\hline FINCA Bank Georgia & $1,06 \%$ & 1,12744 & $1,01 \%$ & 1,0284 & $0,83 \%$ & 0,68506 & $0,63 \%$ & 0,39763 \\
\hline Halyk Bank Georgia & $1,44 \%$ & 2,06433 & $1,49 \%$ & 2,23502 & $1,52 \%$ & 2,32271 & $1,32 \%$ & 1,73695 \\
\hline Isbank Georgia & $0,94 \%$ & 0,89201 & $0,72 \%$ & 0,51708 & $0,59 \%$ & 0,35349 & $0,49 \%$ & 0,23675 \\
\hline TeraBank & $2,28 \%$ & 5,22067 & $2,56 \%$ & 6,57696 & $2,54 \%$ & 6,42971 & $2,33 \%$ & 5,42126 \\
\hline Liberty Bank & $3,32 \%$ & 11,0047 & $3,47 \%$ & 12,0227 & $3,62 \%$ & 13,1277 & $3,69 \%$ & 13,5914 \\
\hline PASHA Bank Georgia & $0,50 \%$ & 0,24953 & $0,05 \%$ & 0,00286 & $0,72 \%$ & 0,51483 & $0,93 \%$ & 0,869137 \\
\hline ProCredit Bank & $4,50 \%$ & 20,2319 & $4,52 \%$ & 20,4489 & $3,89 \%$ & 15,1174 & $3,35 \%$ & 11,224 \\
\hline TBC Bank & $37,48 \%$ & 1404,4 & $38,13 \%$ & 1453,93 & $38,14 \%$ & 1454,93 & $38,66 \%$ & 1494,77 \\
\hline VTB Bank-Georgia & $4,91 \%$ & 24,0622 & $4,35 \%$ & 18,9505 & $4,17 \%$ & 17,3817 & $3,61 \%$ & 13,0425 \\
\hline Ziraat Bank Georgia & $0,08 \%$ & 0,00612 & $0,08 \%$ & 0,00673 & $0,13 \%$ & 0,01687 & $0,15 \%$ & 0,02394 \\
\hline $\mathrm{HHI}$ & \multicolumn{2}{|c|}{$H H \mathrm{HH}=2627.88519$} & \multicolumn{2}{|c|}{$H H \mathrm{H}=2709.46132827101$} & \multicolumn{2}{|c|}{$H H \mathrm{HH}=2740.14092984028$} & \multicolumn{2}{|c|}{$H H=2886.34215089927$} \\
\hline
\end{tabular}

Source: Compiled by the author based on data from the National Bank of Georgia, 2016-2020 [13, 14, 29-32].

According to the methodological guidelines of the Georgian Competition Agency, based on the Herfindahl-Hirschman index, the levels of market concentration are determined as follows: low concentrated - HHI $<1250$; Moderately concentrated - $1250<\mathrm{HHI}<2250$; Highly concentrated HHI $>2250$ [28].

From the data of the Table 2 we conclude, that the level of concentration in Georgian banking sector in 2016-2019 is as follows : HHI (2016) $=2627.885193$; $\mathrm{HHI}(2017)=$ 2709.4613283; HHI (2018) = 2740.1409298; HHI (2019) $=2886.342151$ and therefore, the given method shows that the Georgian banking sector characterized by high concentration (high monopoly).

Based on the research, the concentration rate determined by different methods is characterized by an increasing trend every year and reached its maximum in 2019. The growth of the index is conditioned by the growth of net loans of the two leading banks of the Georgian banking sector - Bank of Georgia and TBC Bank. Therefore, in order to assess the competition in the banking sector, it is important to consider the interest rate spread (see Figure1). 


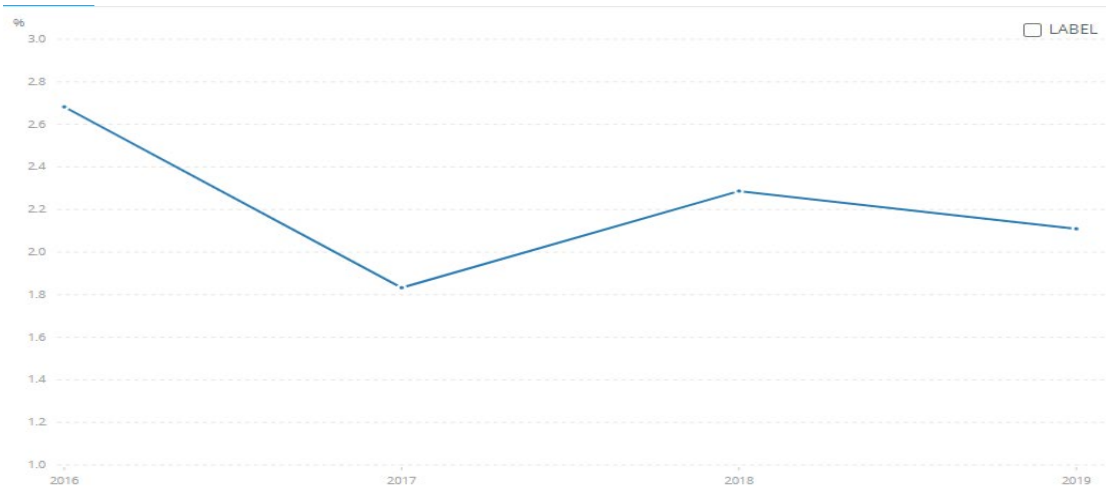

Fig. 1. The interest rate spread in the Georgian banking sector 2016-2019.

Figure 1 shows that the interest rate spread reduce, when the monopoly in the banking sector is increasing. In particular, in 2016 interest rate spread form the high mark $(2.68 \%)$ decreased and in 2017 it was equal to $1.83 \%$. There was very unstable state with interest rate spread $(2018-2.28 \% ; 2019-2.11 \%)$. This highlights the volatile situation in the Georgian banking sector, which is accompanied by the fact that despite the decreasing trend in interest rates, this factor has not had a significant impact on the profitability of the Georgian banking sector. It can be argued, that this positive trend must be accompanied by other important stimulus mechanisms $[33,34]$, that will ultimately have an impact on a competitive environment.

Having discussed the interest rate spread, it is important to analyse the net interest income of commercial banks. Table 3 shows the dynamics of net interest incomes of commercial banks in Georgia in 2016-2019. The monopoly, that we have already, repeatedly proven is clearly seen in the case of net interest income. The two leading banks in the banking sector have the largest share of net interest income, their income dynamics are mostly growing (see Table 3).

Table 3. Net interest income of Georgian commercial banks 2016-2019.

\begin{tabular}{|l|r|r|r|r|}
\hline Commercial Banks & \multicolumn{1}{|c|}{2016} & 2017 & \multicolumn{1}{|c|}{2018} & \multicolumn{1}{c|}{2019} \\
\hline Bank Of Georgia & $32,47 \%$ & $33,83 \%$ & $33,39 \%$ & $34,06 \%$ \\
\hline Basisbank & $4,00 \%$ & $4,13 \%$ & $4,27 \%$ & $5,04 \%$ \\
\hline Silk Road Bank & $0,15 \%$ & $0,11 \%$ & $0,17 \%$ & $0,20 \%$ \\
\hline Credo Bank & $5,84 \%$ & $4,75 \%$ & $4,62 \%$ & $5,24 \%$ \\
\hline Cartu Bank & $4,28 \%$ & $3,91 \%$ & $2,78 \%$ & $2,77 \%$ \\
\hline FINCA Bank Georgia & $2,06 \%$ & $1,83 \%$ & $1,45 \%$ & $1,51 \%$ \\
\hline HalykBank Georgia & $1,05 \%$ & $1,19 \%$ & $1,14 \%$ & $1,05 \%$ \\
\hline Isbank Georgia & $0,51 \%$ & $0,43 \%$ & $0,38 \%$ & $0,54 \%$ \\
\hline TeraBank & $1,64 \%$ & $1,76 \%$ & $1,92 \%$ & $1,91 \%$ \\
\hline Liberty Bank & $9,15 \%$ & $9,53 \%$ & $8,33 \%$ & $7,20 \%$ \\
\hline PASHA Bank Georgia & $1,01 \%$ & $0,81 \%$ & $0,74 \%$ & $0,78 \%$ \\
\hline ProCredit Bank & $4,14 \%$ & $2,77 \%$ & $2,36 \%$ & $2,09 \%$ \\
\hline TBC Bank & $29,69 \%$ & $31,58 \%$ & $35,17 \%$ & $34,48 \%$ \\
\hline VTB Bank-Georgia & $3,84 \%$ & $3,20 \%$ & $3,09 \%$ & $2,84 \%$ \\
\hline Ziraat Bank Georgia & $0,17 \%$ & $0,16 \%$ & $0,20 \%$ & $0,28 \%$ \\
\hline
\end{tabular}

Source: Compiled by the author based on data from the National Bank of Georgia, 2016-2020 [13, 14, 29-32].

Based on the monopoly on net interest income, we considered it expedient to determine the reason of this situation. When we talking about the net interest income, one of the determinants can be the loan interest rates. The figure shows the interest rate of Georgian commercial bank's on mortgage, consumer and business loans (see Figures 2 and 3). 


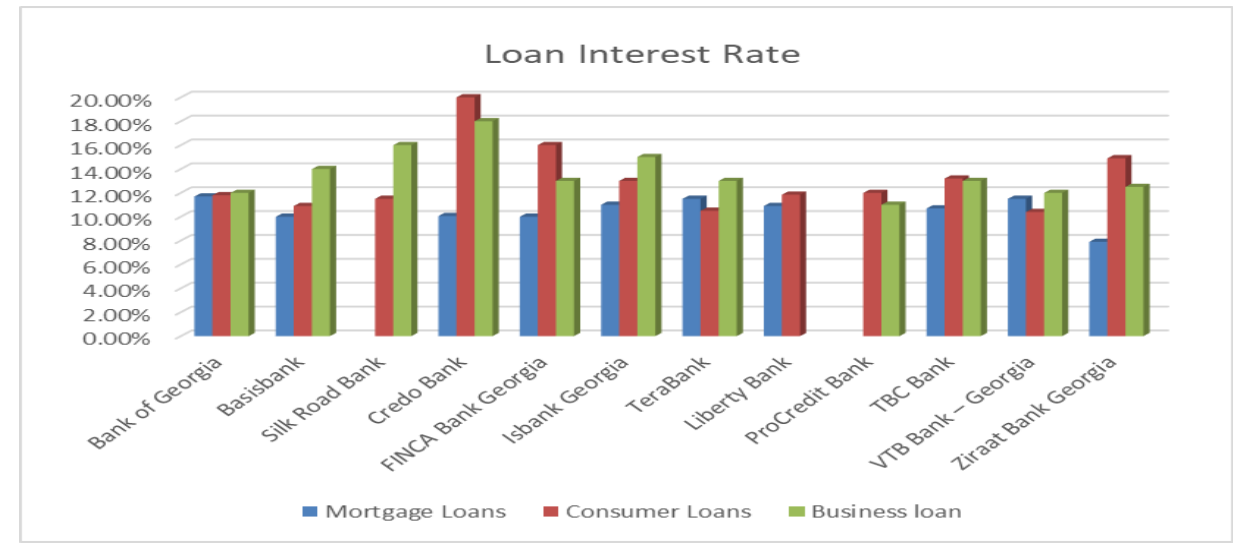

Fig. 2. Loan Interest Rate of Georgian commercial banks [29-32, 35-42].

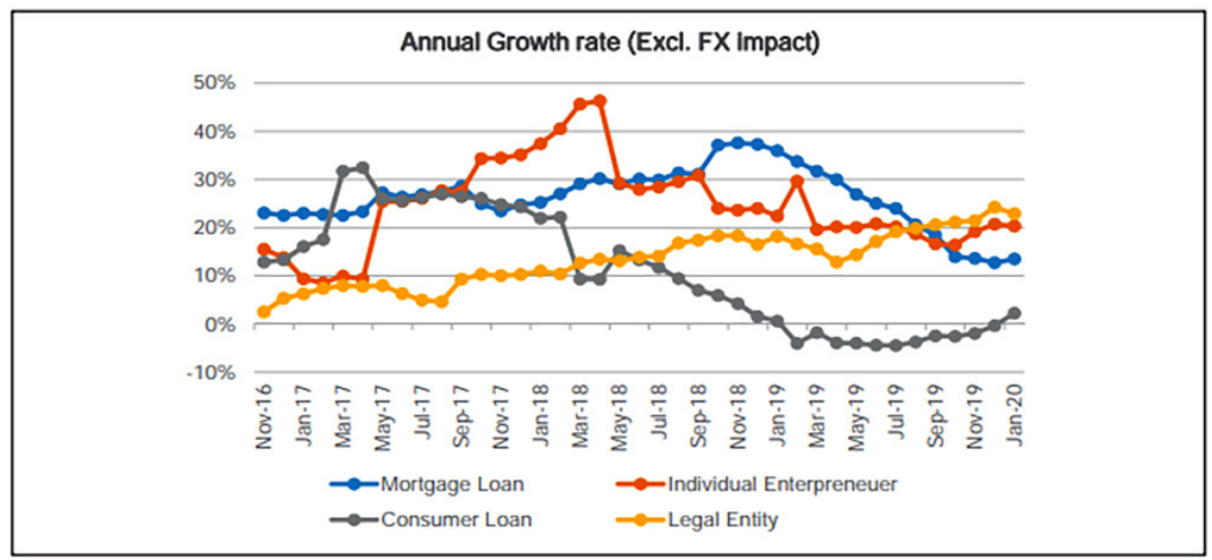

Fig. 3. Annual Growth Rate.

Source: National Bank of Georgia [29-32].

Figures 2 and 3 shows, that the interest rates on mortgage loans, as well as on consumer loans do not differ significantly in the case of different banks. The interest rates on these two loans are non-competitive. As for business loans, there is competition, as banks offer more or less different interest rates, and in the case of this loan, the interest rate set by the two leading banks is more competitive than other types of loans and is acceptable to consumers due to its relatively low rate. This indicates that in the Georgian banking sector these two banks have monopoly rules for a defined loan portfolio. In addition, it can be noted that the noncompetitive environment in the banking sector leads to similar non-competitive interest rates.

Under the influence of monopoly banks and considering their pricing policy, other banks do not have the ability to set lower interest rates on loans. Small banks are unable to reduce interest rates. All of this affects their financial indicators (see Figure 4). 


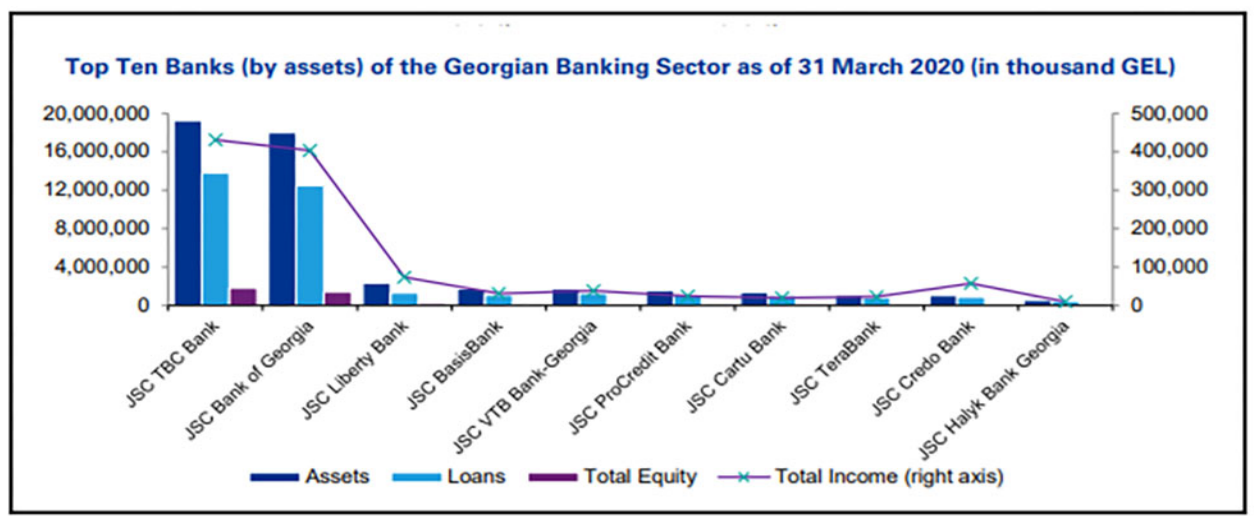

Fig. 4. Top Ten Banks of the Georgian Banking Sector.

Source: National Bank of Georgia, 2020 [29-32].

The financial condition of commercial banks operating in the banking sector of Georgia can be assessed with Figure \#3, which clearly shows the leading position of Bank of Georgia and TBC Bank in terms of assets, loan portfolio, total equity and income.

In 2019 , the return on average assets and equity was $2.2 \%$ and $17.7 \%$, respectively. For 2018 , it was equal to $2.5 \%$ and $19.4 \%$. However, a declining trend is observed in $2017-2019$ (see Figure 5).

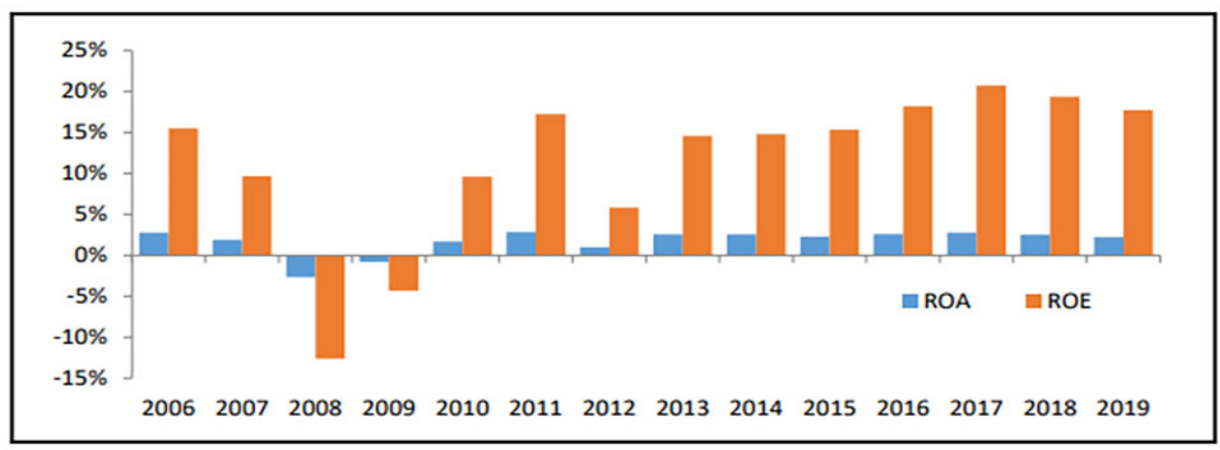

Fig. 5. Return on assets and equity in Georgian banking sector 2006-2019.

Source: National Bank of Georgia, 2020 [29-32].

As the results of research shows, the given indicators characterized by unstable dynamics. The decrease of the interest rate spread is due not to the competition of the bank, but to the conditions of the banking monopoly and, consequently, does not affect the growth of the profit of the banking sector.

\section{Conclusions}

Competition in the banking market has a significant impact on the effective functioning of the banking sector, which, in turn, is related to the well-being of the bank's customers. Competition significantly improves the efficiency of capital investment and reduces risks. This is an important factor for the stability of the money in economy and for inclusive economy growth. However, the monopoly in Georgian banking sector has limited the reduction of interest rates on loans. It also restricts the competition in lending and promotes to increase net interest income for monopoly banks. Competition in the banking market has deteriorated due to the pricing policy of monopoly banks. 
Based on the results of the study, we believe that it is important to make a number of changes in the monetary policy of the National Bank. In particular,

1. The National Bank should limit the monopoly environment in the banking market;

2. Establish banking competition become an important task of the National Bank;

3. The banking market should provide stimulus to the money supply to the economy, while the National Bank should be limited to the function of regulator only.

\section{References}

1. G. Abuselidze, L. Mamaladze, Lecture Notes in Computer Science 12253, 453-467 (Springer, Cham, 2020). doi:10.1007/978-3-030-58814-4_32

2. G. Abuselidze, A. Slobodianyk, Advances in Intelligent Systems and Computing 1258, 718-728 (Springer, Cham, 2021). doi:10.1007/978-3-030-57450-5_61

3. G. Abuselidze, The Influence of Covid-19 on the Public Debt Growth and Default Risk: A Fiscal Sustainability Analysis. Proceedings of the International Scientific and Practical Conference on Sustainable Development of Regional Infrastructure (ISSDRI 2021). (SciTePress, 2021)

4. G. Abuselidze, A. Slobodianyk, E3S Web of Conferences 210, 15016 (2020). doi:10.1051/e3sconf/202021015016

5. J. Bikker, Sh. Shaffer, L. Spierdijk, DNB Working Paper 225, (2009)

6. F. Khodadad Kashi, J. Zarein, Y. Mosavi, Iranian Economic Review 19(1), 29-39 (2015). doi:10.22059/IER.2015.55158

7. J. Maudos, X. Vives, Review of Industrial Organization 55(1), 27-46 (2019). doi:10.1007/s11151019-09687-5

8. C. P. Montes, Journal of Banking \& Finance 43, 124-136 (2014). doi:10.1016/j.jbankfin.2014.03.004

9. R. Najarzadeh, M. Reed, H. Mirzanejad, Journal of Economic Cooperation \& Development 34(1), (2013)

10. M. N. S. Tash, Y. Abdi, Journal of Empirical Economics 1(1), 32-37 (2013)

11. C. A. Northcott, Competition in banking: A review of the literature 2004-24 (Bank of Canada 2004). Available on http://www.bankofcanada.ca/wp-content/uploads/2010/02/wp04-24.pdf

12. H. Gersbach, H. Haller, S. Papageorgiou, Journal of Banking \& Finance 121, 105954 (2020). doi:10.1016/j.jbankfin.2020.105954

13. G. Abuselidze, M. Kizinidze, E3S Web of Conferences 135, 04037 (2019). doi:10.1051/e3sconf/201913504037

14. G. Abuselidze, European Journal of Sustainable Development 10(1), 203-220 (2021). doi:10.14207/ejsd.2021.v10n1p203

15. K. Schaeck, M. Cihak, S. Wolfe, Journal of Money, Credit and Banking 41(4), 711-734 (2009). doi:10.1111/j.1538-4616.2009.00228.x

16. K. Schaeck, M. Cihak, European Financial Management 18(5), 836-866 (2012). doi:10.1111/j.1468-036X.2010.00551.x

17. K. Schaeck, M. Cihak, Financial Management 43(1), 215-241 (2014). doi:10.1111/fima.12010

18. J. H. Boyd, G. De Nicolo, The Journal of finance 60(3), 1329-1343 (2005). doi:10.1111/j.15406261.2005.00763.x

19. S. Claessens, L. Laeven, Journal of the European Economic Association 3(1), 179-207 (2005). doi:10.1162/1542476053295322

20. A.Y.H. Saif-Alyousfi, A. Saha, R. Md-Rus, The North American Journal of Economics and Finance 51, 100867 (2020). doi:10.1016/j.najef.2018.10.015

21. S. Ijaz, A. Hassan, A. Tarazi, A. Fraz, Journal of Business Economics and Management 21(1), 200-221 (2020). doi:10.3846/jbem.2020.11761

22. R. Bukvic, Concentration and Competition in Serbian Banking Sector in the Period 2016-2018. Ekonomika 66(2), 17-35 (2020)

23. J. C. Cuestas, Y. Lucotte, N. Reigl, Post-Communist Economies 32(2), 215-249 (2020). doi:10.1080/14631377.2019.1640981

24. M. Jayakumar, R. P. Pradhan, S. Dash, R. P. Maradana, K. Gaurav, Journal of Economics and Business 96, 15-41 (2018). doi:10.1016/j.jeconbus.2017.12.004 
25. M. Jayakumar, R. P. Pradhan, D. Chatterjee, A. K. Sarangi, S. Dash, Advances in Analytics and Applications, 275-297 (Springer, Singapore, 2019). doi:10.1007/978-981-13-1208-3_21

26. L. Beridze, Proceedings of the International Scientific Conference Challenges of Globalization in Economics and Business (Tbilisi, 2016)

27. H. Dincer, Kybernetes 48(6), 1195-1215 (2019). doi:10.1108/K-02-2018-0055

28. Legislative Herald of Georgia, Law of Georgia on Competition (2021). Available on http://matsne.gov.ge/en/document/view/1659450?publication=9

29. National bank of Georgia, Financial stability 2016-2019 years dates (2020). Available on http://www.nbg.gov.ge/index.php?m=404

30. National Bank of Georgia, Annual report 2016-2019 (2020). Available on http://www.nbg.gov.ge/uploads/publications/annualreport/2019/annual_2018.pdf

31. National Bank of Georgia, New regulations (2020). Available on http://www.nbg.gov.ge/index.php?m=340\&newsid=3545

32. National Bank of Georgia, Annual reports of Georgian commercial banks 2016-2019 (2020)

33. G. Abuselidze, L. Beridze, Proceedings of the 4th International Conference on European Integration (ICEI), 29-41 (2018)

34. G. Abuselidze, A. Slobodianyk, Economic Science for Rural Development 52, 203-221 (2019)

35. Bank of Georgia, Financing (2021). Available on http://bankofgeorgia.ge/en/retail/loans

36. Liberty Bank, Financing and Loans (2021). Available on http://libertybank.ge/en/produqtebi/chemi-biznesistvis/biznes-sesxi

37. Liberty Bank, Term deposits (2021). Available on http://www.libertybank.ge/ka/produqtebi/chemtvis/anabrebi-da-sertipikatebi/vadiani

38. TBC Bank, Business and Personal (2021). Available on http://www.tbcbank.ge/web/en/web/guest/lending

39. TBC Bank, Entered the Uzbek market (2019). Available on http://www.tbcbank.uz/?lang=en

40. TBC Bank, Is the shareholder of Azerbaijan Bank (2018). Available on http://www.nikoil.az/en/news/206/nikoil-bank-enters-into-strategic-partnership-agreement-withtbc-bank.

41. Tera Bank, Consumer loan and mortgage loan (2019). Available on http://www.terabank.ge/ge/retail/loans/consumer-loans

42. VTB Bank, ATM-s and branches (2021). Available on http://vtb.ge/ge/about-thebank/ /m/u/ck/ATMs\%20and\%20branches/GEO-24.04.pdf 